\title{
PENATAAN LEMBAGA NEGARA MANDIRI DALAM STRUKTUR KETATANEGARAAN INDONESIA
}

\author{
Retno Mawarini Sukmariningsih*
}

Bagian Hukum Tata Negara, Fakultas Hukum Universitas Tujuh Belas Agustus 1945, Semarang Jalan Pawiyatan Luhur Bendan Dhuwur, Semarang, Jawa Tengah 50233

\begin{abstract}
This purpose of this article is to harmonize and to synchronize regulations of independent state agencies in order to avoid from the overlapping within those agencies so that they persistently can exercise their function, and further to analyze them normatively as ad-hoc commissions under the effective regulations or otherwise. The rearrangement is purported to reconstruct the regulations of independent state agencies and it must begin from the constitution so that we internally can simplify to supervise and to minimize abuse of power carried on by the independent state agencies in order to answer people's serious challenge.
\end{abstract} Keywords: regulation, constitution, independent state agencies.

\section{Intisari}

Tulisan ini mempunyai tujuan agar ada harmonisasi regulasi lembaga negara mandiri supaya sesama lembaga negara mandiri tidak overlapping dalam menjalankan fungsinya dan lebih jauh lagi untuk mengkaji secara normatif lembaga negara mandiri seperti komisi-komisi yang dibentuk secara ad-hoc dalam peraturan perundang-undangan jauh lebih efektif atau justru sebaliknya. Penataan regulasi ini bermaksud untuk penataan regulasi kelembagaan negara khususnya lembaga negara mandiri yang diawali dari konstitusi, sehingga akan memudahkan pengawasan secara internal dan meminimalisir penyalahgunaan kekuasaan lembaga negara mandiri yang pembentukannya mestinya untuk menjawab tantangan kebutuhan masyarakat.

Kata Kunci: regulasi, konstitusi, lembaga negara mandiri.

\section{Pokok Muatan}

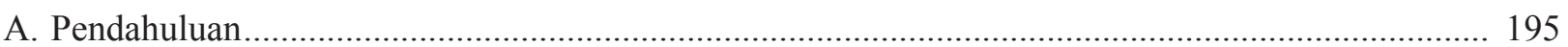

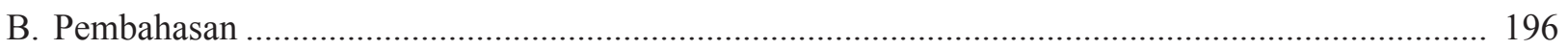

1. Hakekat Prinsip Checks and Balances dalam Negara Hukum .................................................. 196

2. Penataan Regulasi Lembaga Negara Mandiri dalam Konstitusi ................................................. 200

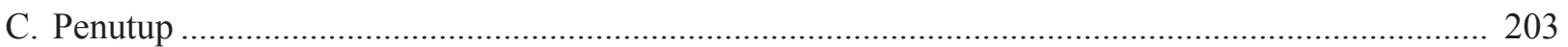

Alamat Korespondensi: sukma_retno@hotmail.com 


\section{A. Pendahuluan}

Tuntutan reformasi membawa dampak adanya amandemen UUD 1945, penghapusan doktrin dwi fungsi ABRI, penegakan hukum, HAM dan pemberantasan KKN serta mewujudkan kehidupan demokrasi. Terhadap penyelenggaraan negara perubahan konstitusi biasanya dibarengi dengan pembentukan lembaga-lembaga negara mandiri, dengan asumsi sebagai jawaban kompleksitas persoalan ketatanegaraan, tetapi justru kompleksitas persoalan ketatanegaraan itu dapat dimulai dari terbentuknya lembaga negara mandiri yang baru dibentuk hasil perubahan konstitusi. Yang selama ini sering terjadi adalah tidak dibarengi harmonisasi peraturan perundangundangan bahkan terjadi overlapping kekuasaan. Sebetulnya reformasi konstitusi mempunyai tujuan mulia untuk membangun pemerintahan Indonesia semakin demokratis hanya saja dalam aplikasinya memerlukan komitmen bersama antara rakyat dengan pemerintah untuk mewujudkannya.

Di Amerika terjadi perdebatan sengit antara para cendekiawan hukum yang membedakan fungsi dari lembaga negera independen secara formalitas atau fungsionalitas. Menurut Deborah N. Pearlstein, para formalis menyelidiki dengan identikasi secara fundamental dari hakekat fungsi-fungsi "eksekutif" dan "legislatif", meskipun penyelidikan ini menyiratkan suatu kesulitan mengenai keberadaan dari kekuatan ide-ide pemerintahan yang dicetuskan oleh Plato yang mungkin atau tidak mungkin sejalur dengan bentuk-bentuk umum dari penyelenggaraan negara. ${ }^{1}$ Mereka harus menghadapi realitas kehidupan di dalam negara dengan administrasi modern (modern administrative state), dimana adanya kepatuhan yang ketat terhadap bagianbagian kekuasaan formal yang kemungkinan berdampak akan terjadinya banyak pembongkaran dari badan-badan di bawah naungan eksekutif dalam kehidupan sehari-hari terlibat dalam pembuatan undang-undang (legilastif dan eksekutif) dan fungsi peradilan (yudikatif). ${ }^{2}$ Pada waktu yang sama, efektifitas dari para fungsionalis berjuang untuk menyatukan efisiensi kepentingan-kepentingan dan keefektifitasan untuk satu cabang tertentu, dengan prinsip pemisahaan kekuasaan secara menyeluruh dan dapat ditegaskan disini bahwa tidak ada salah satu cabang pun yang dalam menjalankan fungsinya tanpa dibatasi atau memerintah secara tirani. ${ }^{3}$ Setiap tujuan fungsionalis menghadapi pula tuntutan yang memberikan semacam ruang yang luas dengan pertimbangan untuk meninggalkan batas-batas struktural pemerintahan yang terbuka terhadap tingkat ketidakpastian dan ketidakkonsistenan dari ide hukum dalam demokrasi konstitusional. ${ }^{4}$

Denny Indrayana dalam disertasinya yang berjudul "Indonesian Constitution Reform 19992002 An Evaluation of Constitutional-Making in Transition" mengemukakan 2 (dua) elemen dasar dari konten demokrasi konstitusional, yaitu adanya pemisahan kekuasaan dan perlindungan terhadap Hak Asasi Manusia (HAM), dan menurutnya tanpa adanya kedua elemen tersebut, sebuah konstitusi menjadi a "dead" letter dan dapat ditolak dalam kehidupan politik sehari-hari. ${ }^{5}$ Hal senada juga diungkapkan oleh Adnan B. Nasution yang menegaskan bahwa demokrasi yang benar adalah demokrasi dari, oleh dan untuk rakyat, oleh karena itu dalam membentuk suatu negara yang demokrasi konstitutional diperlukan 3 (tiga) karakteristik penting, diantaranya: Pertama, ada kemerdekaan politik dari rakyat, yang meliputi kemerdakaan berpikir, berpendapat, berkumpul, dan berorganisasi; Kedua, ada pembatasan kekuasaan

\footnotetext{
Deborah N. Pearlstein, "Form And Function In The National Security Constitution”, Connecticut Law Review, Vol. 41, No. 5, Juli 2009, hlm. 1558-1559.

Ibid.

Ibid.

Ibid.

Denny Indrayana, 2008, Indonesian Constitution Reform 1999-2002 An Evaluation of Constitutional-Making in Transition, Kompas Book Publishing, Jakarta, hlm. 76.
} 
artinya kekuasaan penyelenggara negara (penguasa) harus dibatasi dengan berbagai cara dan mekanisme pembatasan, checks and balances dan kontrol; Ketiga, adanya jaminan hak asasi manusia. ${ }^{6}$

Kompleksitas persoalan-persoalan ketatanegaraan mulai mengemuka ketika terjadi perubahan paradigma dalam penyelenggaraan pemerintahan, masa transisi dari otoritarian menjadi demokratis merupakan perjuangan yang tidak mudah seperti membalikkan tangan tetapi lebih dari itu perjuangan untuk mengendalikan kekuasaan pemerintah dianggap lebih mudah dengan membentuk lembaga lembaga negara baru yaitu lembaga negara mandiri, dikarenakan pengalaman pahit dari bekapan otoritarian masa lalu menjadi pengalaman sejarah bagi bangsa Indonesia untuk bangkit dari keterpurukan.

Terjadinya berbagai krisis seperti krisis kepercayaan terhadap penyelenggara negara juga merupakan salah satu indikator terbentuknya lembaga-lembaga negara yang mempunyai label mandiri yang kemudian justru menambah kompleksitas persoalan. Hal ini perlu diupayakan penataan atau rekonstruksi yang diawali dari penataan grand desain kelembagaan negara dalam konstitusi melalui perubahan. Rekonstruksi atau penataan kembali lembaga-lembaga negara mandiri dalam struktur ketatanegaraan Indonesia akan terjalin suatu keharmonisan dan sinkronisasi antara lembaga-lembaga tersebut, penataan kembali yang didasarkan pada pengaturan perundang-undangan diharapkan tidak akan terjadi tumpang-tindih atau overlapping.

\section{B. Pembahasan}

\section{Hakekat Prinsip Checks and Balances dalam Negara Hukum}

Dalam memahami tujuan hukum ada beberapa teori hukum yang sangat berpengaruh pada zaman modern yang terkait dengan pemikiran secara filosofis, moral dan politik seperti faham utilitarian, deontology dan hukum kebajikan. Menurut faham utilitarian yang dipelopori oleh Jeremy Bentham. Bahwa hukum harus dirancang atas dasar prinsip-prinsip moralitas agar hukum membawa kebahagiaan bagi kebanyakan orang (greatest happiness principle), prinsip ini adalah untuk memberikan pondasi sistem, tujuannya yaitu membangun pabrik kebahagiaan dengan bantuan penalaran dan hukum.

Pengembangan konsep dari Bentham ini sampai pada faham kesejahteraan (welfarism), hak-hak binatang (animal rights), dan panopticon (rancangan penjara yang secara khusus untuk memudahkan pengawasan) sedangkan faham deontology dari Immanuel Kant mengemukakan bahwa hukum harus melindungi setiap otonomi individu, kebebasan individu, dan hak-hak individu kemudian hukum kebajikan (virtue jurisprudence) pada dasarnya ingin menggabungkan ke duanya sehingga hukum harus mencerminkan perilaku dan karakter masyarakat yang baik dan dilihat dari ketaatan serta manfaatnya. ${ }^{8}$

Kant membedakan menjadi tiga keadilan publik hak-hak asasi yang berasal dari hakekat manusia atau yang diberikan oleh negara (public justice as related to the natural and the civil state), diantaranya: ${ }^{9}$ (1) protective justice (justitia testatrix) yaitu keadilan adalah hak-hak dasar manusia (hak yang berasal dari hakekat manusia) dicantumkan dalam bentuk peraturan perundang-undang (lex justice); (2) keadilan yang sesuai dengan hukum terkait dengan tujuan dan keadilan adalah memberikan kepada orang lain apa yang menjadi haknya (lex juridical); dan (3) keadilan dinyatakan dengan apa yang benar dan apa yang adil, dan lebih

\footnotetext{
Adnan Buyung Nasution, 2007, Arus Pemikiran Konstitutionalisme Hak Asasi Manusia dan Demokrasi, Kata Penerbit, Jakarta, hlm. 199. J.H Burn, "Happiness and Utility: Jeremy Bentham's Equation”, University College London, Vol. 17, No. 1, Maret 2005, hlm. 48. Lihat pula Ruut Veenhoven, "Happiness as an Aim in Public Policy The Greatest Happiness Principle", http://www2.Eur.Nl/Fsw/Research/Veenhoven, diakses 12 Maret 2013.

Roscoe Pound, 2002, The Ideal Element in Law, Liberty Fund, Indianapolis, hlm. 203.

Immanuel Kant, 1887, The Philosophy of Law An Exposition of the Fundamental Principles of Jurisprudence as The Science of Right, (Terj. W. Hastie), B.D, T \& T Clark, Edinburg, hlm. 155.
} 
luas lagi adalah putusan pengadilan untuk kasus tertentu berdasarkan hukum yang berlaku.

Perkembangannya, ilmu hukum modern sangat dipengaruhi oleh teori dari Bentham seperti teori negara kesejahteraan (welfare state), seperti di Indonesia sebetulnya komitmen para pendiri negara Indonesia tentang negara kesejahteraan sudah ada dalam Pembukaan UUD NRI Tahun 1945 alinea ke IV yang di dalamnya juga tersurat keinginan Pembentuk Negara untuk melindungi segenap bangsa Indonesia dan seluruh tumpah darah Indonesia, memajukan kesejahteraan umum, mencerdaskan kehidupan bangsa, dan melaksanakan ketertiban dunia yang mendasarkan pada kemerdekaan, perdamaian abadi, dan keadilan sosial. Selanjutnya tinggal bagaimana semangat para penyelenggara negara ini mewujudkannya. John Rawls dalam theory of justice mengemukakan bahwa konsekuensi yang logis diukur dari keadilan, sehingga dapat diartikan bahwa tujuan hukum sebenarnya untuk mewujudkan keadilan bagi masyarakat umum. ${ }^{10}$ Teori dari John Rawls ini juga merupakan kritik yang ditujukan kepada Bentham bahwa pengertian kebahagiaan mempunyai makna sangat relatif dan sulit untuk diukur. Keadilan dan kebahagiaan merupakan sesuatu hal yang sulit untuk diukur tetapi paling tidak dalam konteks penataan regulasi lembaga negara mandiri menerapkan check and balances agar tidak terjadi overlapping kewenangan.

Dalam negara hukum, menurut Azhary, antara pengawasan secara normatif dengan negara hukum memiliki hubungan yang erat, karena prinsip negara hukum adalah meletakkan hukum sebagai landasan utama dalam kehidupan bermasyarakat, berbangsa dan bernegara, dan disamping prinsip negara hukum adalah meniadakan absolutisme kekuasaan atau adanya pembatasan kekuasaan. ${ }^{11}$ Sementara
H. Franken etal memberikan ciri-ciri dari negara hukum (rechtstaat), diantaranya: ${ }^{12}$

a. $\quad E r$ is een consitutie die bedinde voorschriften bevat voor de betrekking tussen overheid en burgers (ada sebuah konstitusi yang memuat peraturan/ ketentuan mengikat untuk hubungan pemerintah dan warga negara).

b. In deze constitutie wordt een scheiding van machten verzekerd, waarbij wordt vereist dat (di dalam konstitusi ditentukan sebuah pemisahan kekuasaan yang diwujudkan dengan):

1. wetgeving tot stand komt door of in overeenstemming met het parlement (pembuatan undangundang berasal dan disepakati oleh parlemen).

2. er een onafhankelijke rechterlijke macht bestaat, die niet alleen geschillen tussen de burgers onderling, maar ook die tussen overheid en burgers beslist (adanya kekusaan kehakiman yang merdeka yang tidak hanya memutus perselisihan/ perkara diantara warga negara, tetapi juga diantara pemerintah dan warga negara).

3. het optreden van het bestuur op de wet berust (tindakan pemerintah yang berdasarkan pada Undang-Undang).

c. In de konstitutie worden de grondof vrijheidsrechten van de burgers omgeschreven en gewaarborgd. (hakhak dasar dan kebebasan warga negara tercantum dan dijamin di dalam konstitusi.

Merujuk dari pendapat yang dikemukan oleh Jeremy Waldron, hakekat dari negara hukum adalah "True, the rule of law is not the only value that lawyers serve. Lawyers must serve justice too, for justice is part of law's promise". ${ }^{13}$

\footnotetext{
10 Nick J. de Boer, "Fundamental Rights and the EU Internal Market: Just how Fundamental are the EU Treaty Freedoms? A Normative Enquiry Based on John Rawls' Political Philosophy", Utrecht Law Review, Vol. 9, No. 1, Januari 2013, hlm. 149-150.

Azhary, 1995, Negara Hukum Indonesia, Analisis Yuridis Normatif tentang Unsur-Unsurnya, UI Pres, Jakarta, hlm 33.

12 Franke, H, et al., 1990, Inleiden tot Rechtswetenschap, Gouda Quint D. Brouwer en zoon, Arnhem, hlm. 293.

13 Jeremy Waldron, "The Rule of International Law", Harvard Journal of Law \& Public Policy, Vol. 30, No.1, 2006, hlm. 15.
} 
Hal tersebut memberikan pemahaman bahwa segala sesuatu bidang kehidupan akan diatur dengan hukum untuk itu hukum akan dibuat setiap saat. Namun yang harus menjadi perhatian secara seksama dari pembuat undang-undang (wetgever) atau pembentuk Undang-Undang (rechtsvormer) bahwa undang-undang seharusnya menjadi hukum yang baik dan memenuhi tuntutan rasa keadilan (het recht moet, om goed recht te zijn, aan de eis van rechtvaardigheid voldoen). ${ }^{14}$ Oleh karena itu, J. H. P. Bellefroid menyatakan bahwa pembuat UndangUndang (wetgever) atau pembentuk UndangUndang (rechtsvormer) mempunyai kewajiban menentapkan keadilan ke dalam hukum positif, selanjutnya dia menjelaskan:

Een rechtsregel, die geheel in strijd met de rechtvaardigheid, is slecht recht en mist bijgevolg inneerlijke rechtskwaliteit, hoewel hij, formeel, voor zover hij door een bevoeg gezag is vastgesteld, tot het stellige recht behoort. ${ }^{15}$

Pembuatan hukum yang tidak memberikan manfaat bagi rakyat tentu saja sangat tidak diharapkan karena hanya akan menjadi sia-sia dan tidak berguna. Dalam perspektif yang demikian maka pengawasan secara normatif sangat diperlukan sebagai bagian dari pelaksanaan prinsip negara hukum, sehingga produk hukum yang dihasilkan oleh lembaga kekuasaan negara tidak akan terjadi overlapping. Bahkan berdasarkan hasil survei World Economic Forum (WEF) mencatat pada kurun waktu 2001-2005, kepercayaan masyarakat kepada pemerintah sangat merosot di 14 (empat belas) negara, termasuk Indonesia. Bahkan hambatan investasi di Indonesia diantaranya sebesar $21 \%$ disebabkan oleh birokrasi yang tidak efisien (WEF,
2005). Bahkan tidak jarang aparat negara yang melakukan pembiaran atas beberapa keluhan yang di sampaikan oleh masyarakat, lemahnya kepastian hukum, sampai kepada tumpang tindihnya regulasi pada lembaga negara menjadi bahasan yang menarik untuk selalu dikaji.

Penataan kelembagaan negara yang dilakukan merupakan pembatasan kekuasaan agar fungsi dan tanggung jawab masing-masing badan negara dapat dilaksanakan dan dapat diciptakan suatu kondisi check and balances atas kekuasaan-kekuasaan pada lembaga negara. Keberadaan hukum tata negara dalam kehidupan berbangsa dan bernegara, mempunyai peran penting dalam rangka penataan kehidupan kenegaraan dan kemasyarakatan atas dasar sistem yang diacu dalam konstitusi. ${ }^{16}$ Mahfud MD menekankan bahwa hukum tata negara yang berlaku sekarang ini adalah segala sesuatu yang tertulis di dalam konstitusi negara Indonesia, meskipun terjadi pro dan kontra antara suka dan tidak suka atau sesuai atau tidak sesuai berdasarkan teori atau ilmu konstitusi, dan cocok atau tidak cocok dengan apa yang berlaku di negara-negara lain. ${ }^{17}$ Selanjutnya dia menekankan mengenai pokok-pokok yang tertulis di dalam konstitusi yang dibuat melalui prosedur secara konstitusional maka itulah yang berlaku, diterima dan dilaksanakan untuk menghindari campuraduk antara pandangan yang ideal-teoritis dan penuangan resmi yang riilkonstitutif. ${ }^{18}$

Sebelumnya, kita dapat memetik pelajaran dari sebuah peran khusus dalam ranah pemikiran Anglo-Amerikan mengenai checks and balances dimainkan oleh pengadilan-pengadilan yang merujuk dari pemikiran Madison, Hamilton dan Jay di tahun 1988 atau pendapat dari Hayek (1960)

\footnotetext{
J.H.P. Bellefroid, 1952, Inleiding tot de Rechtswetenschap in Nederland, Dekker \& De Vegt N.V. Nijmegen, Utrecht, hlm. 3.

Ibid, terjemahan bebasnya: "Suatu peraturan perundang-undangan, yang seluruhnya bertentangan dengan keadilan, adalah hukum yang buruk dan berdampak ke dalam isi kualitas hukumnya, meskipun peraturan itu ditetapkano oleh otoritas yang berwewenang menjadi hukum positif”. Jimly Asshiddiqie, 2005, Hukum Tata Negara dan Pilar-Pilar Demokrasi, Konstitusi Press, Jakarta, hlm. 154.

Moh. Mahfud MD, 2010, Perdebatan Hukum Tata Negara Pasca Amandemen Konstitusi, Raja Grafindo Persada, Jakarta, hlm. 36.

Ibid.

Rafael La Porta, et al., "Judicial Checks and Balances”, Journal of Political Economy, Vol. 112, No. 2, 2004, hlm. 446. Bandingkan dengan pendapat Hans Kelsen yang menyatakan: "The principle would seem to require that none of three powers should be controlled by any of the other two. It is nevertheless the principle of the separation of powers which is invoked to justify the strictest control of administration by courts, a sate which is reached where the administrative organs have to turn to the courts for enforcement of the administrative law", dalam Hans Kelsen, 1973, The General Theory of Law and State, (Terj. Anders Wedberg), Russel \& Russel, Newyork, hlm. 280.
} 
dan Buchanan (1974). ${ }^{19}$ Friedrich A. von Hayek membedakan dua cara yang mana kekuasaan kehakiman dapat membatasi kekuasaan dari cabangcabanglain.Pertama, penciptaan hukum-hukum dan administrasi pengadilan dapat dipisahkan. Pembuat Undang-Undang (legislatures) membuat peraturan perundang-undangan, akan tetapi kebebasan hakim yang menegakkan peraturan perundang-undangan itu, tanpa adanya intervensi dari pihak legislatif maupun eksekutif. Kedua, pembuatan hukum dan kebijakan dapat dengan sendirinya di-review oleh pengadilan-pengadilan agar tidak bertentangan dengan konstitusi (inconstitutional). ${ }^{20}$

Pergeseran kewenangan membentuk Undang-Undang dari eksekutif ke legislatif menjadi pertanda diakhirinya prinsip "pembagian kekuasaan" (distribution of power) menjadi "pemisahan kekuasaan" (separation of power) dengan cirinya yang menganut prinsip check and balances yang tidak bisa dipisahkan dari prinsip pemisahan kekuasaan. Prinsip checks and balances, idealnya ada pembatasan kekuasaan, kontrol atau pengawasan secara maksimal, sehingga dapat diminimalisir penyalahgunaan wewenang baik oleh aparat pemerintah maupun secara individual yang kebetulan sedang menduduki jabatan pada lembagalembaga negara.

Pemahaman lebih dalam mengenai lembaga negara atau organ negara dapat mengacu pandangan dari Hans Kelsen dalam tulisannya the Concept of the State-Organ dalam bukunya yang berjudul The General TheoryofLawand State. Kelsen mengatakan bahwa "Whoever fulfils a function determined by legal order is an organ" artinya siapa saja yang melaksanakan suatu fungsi yang ditentukan oleh tatanan hukum adalah suatu organ. ${ }^{21}$ Fungsi-fungsi yang dijalankan oleh organ atau lembaga negara diantaranya berkarakter penciptaan norma (a norm-

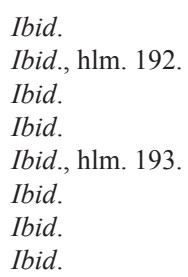

creating) dan penerapan norma (a norm-applying) yang kesemuanya itu diperuntukkan untuk suatu pengeksekusian sanksi hukum, contohnya parlemen yang mengesahkan criminal code (KUH Pidana), dan rakyat yang memilih parlemen adalah organorgan negara, sebagaiman hakim-hakim yang menjatuhkan hukuman kepada setiap individu yang bersalah. $^{22}$

Dalam hal ini, sebuah organ adalah pemenuhan kewajiban secara individu berdasarkan fungsinya sendiri-sendiri, kualitas dari setiap individu dari sebuah organ ditentukan oleh fungsinya. Berikutnya Kelsen mengatakan bahwa "He is an organ because and in so far as he performs a law-creating or lawapplying action". ${ }^{23}$ Kelsen memberikan contoh bahwa hakim adalah sebuah lembaga negara dalam arti sempit karena seoarang hakim dipilih dan ditunjuk sesuai fungsinya, dikarenakan dia harus bertugas sesuai jabatannya secara profesionalitas dan oleh karena itu dia menerima pembayaran reguler atau gaji dari negara yang berasal dari keuangan negara. ${ }^{24}$ Kekayaan negara ini bersumber dari pendapatan negara (the state as subject as property is the Fisc (Fiscus)), pendapatan ini bersumber dari impost dan taxes yang dibayar oleh warga negara. ${ }^{25}$ Terdapat karakteristik penting dari sebuah organ atau lembaga negara dalam arti sempit: lembaga negara yang ditunjuk atau dipilih untuk tujuan terntentu; pelaksanaan fungsinya menjadi keutamaan atau bahkan secara hukum dapat bersifat eksklusif; dan organ tersebut berhak menerima gaji dari keuangan negara. ${ }^{26}$ Lembaga negara bukan hanya individu saja misalkan hakim, pejabat publik/negara ataupun seorang putra mahkota yang menduduki tahtanya karena warisan dari orang tuanya baik raja maupun ratu. Suksesi ini tanpa memerlukan suatu Undang-Undang khusus karena dengan sendiri sudah menjadi hak dari anak seorang raja sebagai putra atau putri mahkota. ${ }^{27}$ 
Tentunya sangat berbeda apabila ada sebuah lembaga negara yang "diciptakan" dengan cara penunjukkan, dipilih atau bahkan diundi. Perbedaan antara penunjukkan dan pemilihan terletak di karakater dan posisi hukumnya dalam menciptakan lembaga tersebut. Sebuah lembaga yang "ditunjuk" oleh suatu badan individu yang superior. Lembaga lain yang dipilih oleh suatu lembaga kolegial, terdiri dari individu-individu disubordinasikan kepada organ atau lembaga terpilih. ${ }^{28}$ Misalkan pembentukan komisi-komisi negara yang pembentukannya bersumber dari konstitusi dan Undang-Undang yang dibentuk oleh parlemen dan pemerintah. Hal ini menunjukkan adanya suatu lembaga superior, yang mampu menciptakan lembaga-lembaga Negara lain, meskipun ketika lembaga-lembaga itu telah berdiri namun lembaga superior tidak dapat diintervensi atas larangan undang-undang yang membentuknya.

Perwujudan adanya prinsip checks and balances antara lain adalah pembentukan UndangUndang yang dilakukan secara demokrasi yang dipahami dengan memperhatikan kedaulatan rakyat dalam membentuk Undang-Undang dan kekuasaan negara dapat di kontrol sedangkan konflik-konflik mengenai kewenangan pada kelembagaan negara sebatas sengketa antar lembaga negara yang kewenangannya diberikan oleh (UUD NRI Tahun 1945) masih bisa diselesaikan melalui lembaga negara yang disebut Mahkamah Konstitusi, tetapi jika kewenangannya tidak diatur oleh UUD 1945 maka Mahkamah Konstitusi tidak dapat menyelesaikannya sehingga perlu ada upaya penyelesaiannya, karena pergeseran pergeseran dalam struktur ketatanegaraan hal ini bisa saja terjadi.

\section{Penataan Regulasi Lembaga Negara Mandiri dalam Konstitusi}

Persoalan lembaga negara mandiri tidak dapat dilepaskan dari keunikan Pasal 24B UUD NRI Tahun 1945 yang disebutkan bahwa Komisi Yudisial bersifat mandiri. ${ }^{29}$ karena pengaturan Komisi Yudisial ada di dalam UUD NRI Tahun 1945 menimbulkan pertanyaan besar kenapa hanya Komisi Yudisial yang diatur dalam Konstitusi? Jika dilihat dari fungsinya bukankah komisi yang lain seperti Komisi Hak Asasi Manusia lebih mempunyai peran yang besar dalam perlindungan hak asasi manusia yang tujuannya dibentuk barangkali untuk mewujudkan cita-cita luhur bangsa Indonesia yang diamanahkan dalam pembukaan UUD NRI Tahun 1945 alinea ke empat dan untuk mewadahi Pasal 28A sampai dengan Pasal 28J. ${ }^{30}$ Selain dari pada itu Komisi Kepolisian Nasional (Kompolnas) berkedudukan di bawah dan bertanggung jawab kepada Presiden yang dilihat dari tugasnya membantu Presiden dalam menetapkan arah kebijakan Kepolisian Negara RI selain itu mempunyai kewenangan memberikan saran dan pertimbangan kepada Presiden untuk mewujudkan Polri yang professional dan mandiri yang tidak kalah pentingnya

Selanjutnya wewenang Kompolnas adalah menerima saran dan keluhan masyarakat mengenai kinerja kepolisian dan kemudian menyampaikannya kepada Presiden. Dalam UU No. 2 Tahun 2002 tentang Polri jo. Peraturan Presiden No. 17 Tahun 2005 tentang Kompolnas yang dimaksud keluhan adalah pengaduan masyarakat yang menyangkut penyalahgunaan wewenang dugaan korupsi, pelayanan yang buruk, perlakuan diskriminasi, dan penggunaan diskresi yang keliru.

29 Lihat Pasal 24B ayat (1), (2), dan (4) dari Undang-Undang Dasar Negara Republik Indonesia Tahun 1945. Pasal 24B ayat (1) Komisi Yudisial bersifat mandiri yang berwenang mengusulkan pengangkatan hakim agung dan mempunyai wewenang lain dalam rangka menjaga dan menegakkan kehormatan, keluhuran martabat, serta perilaku hakim. Ayat (2) "Anggota Komisi Yudisial harus mempunyai pengetahuan dan pengalaman di bidang hukum serta memiliki integritas dan kepribadian yang tidak tercela”. Lihat juga ayat (4) Susunan, kedudukan, dan keanggotaan Komisi Yudisial diatur dengan Undang-Undang.

30 Lihat Pasal 28A Undang-Undang Dasar Negara Republik Indonesia Tahun 1945 bahwa "Setiap orang berhak untuk hidup serta berhak mempertahankan hidup dan kehidupannya", Pasal 28B ayat (1) "Setiap orang berhak membentuk keluarga dan melanjutkan keturunan melalui perkawinan yang sah". 
Dalam Pasal 30 ayat (2) UUD NRI Tahun 1945, Tentara Nasional Indonesia dan Kepolisian Negara Republik Indonesia sebagai kekuatan utama untuk pertahanan dan keamanan negara dan ayat (4) Kepolisian Negara Republik Indonesia mempunyai tugas melindungi, mengayomi, melayani masyarakat, serta menegakkan hukum. ${ }^{31}$ Pasal 30 UUD NRI Tahun 1945 juga mempunyai peran besar terhadap pertahanan dan keamanan serta perlindungan, pengayoman, pelayanan dan penegakan hukum di Indonesia. Dilihat dari fungsinya pasal tersebut diatas yaitu Pasal 28A sampai 28J dan Pasal 30 juga mempunyai peran yang sangat besar tetapi keberadaannya tidak secara tegas di atur dalam konstitusi hal ini menunjukkan ketidakkonsistennya para desainer kebijakan untuk mengatur lembaga negara yang bersifat mandiri, kriteria apa yang bisa dimasukkan ke dalam konstitusi, kalau hanya didasarkan pada peran dan fungsi dari masing-masing lembaga negara mandiri, contoh diatas sudah cukup untuk dapat menjawab bahwa peran dan fungsi bukan salah satu hal yang dapat dijadikan kriteria bahwa lembaga negara mandiri tersebut dapat diatur dengan konstitusi dan lembaga negara mandiri mana yang tidak perlu diatur dengan konstitusi walaupun hanya satu pasal tetapi cukup untuk diperbandingkan kemudian diadakan pengkajian. Pembahasan tersebut di atas tiada lain hanyalah ingin menunjukkan bahwa tugas Kompolnas tidak kalah pentingnya dengan Komisi Yudisial yang pembentukannya berdasarkan amanah konstitusi walaupun hanya satu pasal.

Dalam konteks sejarah negara Indonesia yang sedang mengalami masa transisi dari pemerintahan otoriter menuju pemerintahan yang demokrasi, pembentukan lembaga-lembaga negara mandiri ini dianggap merupakan jawaban untuk melakukan kontrol yang tepat dari kekuasaan pemerintahan. Hampir 15 (lima belas) tahun pasca reformasi merupakan saatnya Majelis Permusyawaratan
Rakyat (MPR) meninjau kembali desain UUD NRI Tahun 1945 khususnya mengenai kelembagaan negara. Penataan kembali kelembagaan negara, termasuk lembaga negara mandiri bisa dibarengi dengan perubahan konstitusi, hal ini biasanya menjadi pertanda tumbangnya pemerintahan otoritarian dalam menuju pemerintahan yang demokrasi. Sekaligus dalam perubahan konstitusi idealnya dibarengi dengan pengaturan mengenai tugas, fungsi, kedudukan bahkan penyebutan dari lembaga negara mandiri. Sehingga tidak dimungkinkan adanya sengketa mengenai kewenangan antara lembaga negara karena kedudukan dari lembaga negara mandiri sudah diatur. Pengaturan mengenai kelembagaan negara barangkali bisa diatur tersendiri dalam satu Bab dalam konstitusi yang didalamnya termasuk komisikomisi negara. Pengaturan lembaga negara mandiri dapat ikut memperkuat adanya pemerintahan demokrasi yang konstitusional. Overlapping aturan satu dengan yang lain disebabkan karena peraturan perundang-undangan yang berlaku tidak sejalan dengan kebijakan politik dan ketatanegaraan yang sedang berkembang.

Pembentukan lembaga-lembaga negara mandiri yang mempunyai penyebutan berbedabeda, membuat ketidakjelasan dalam pertanggungjawabannya, Hal ini perlu diadakan penataan kelembagaan dari aspek konsistensi penyebutan yang kemudian diikuti pertanggungjawabannya dalam suatu regulasi yang secara spesifik mengatur mengenai lembaga negara mandiri. Sebagai lembaga negara mandiri atau sering disebut lembaga independen yang terlepas dari hubungan secara struktural dengan pemerintah barangkali tidak mempunyai kewajiban untuk bisa memberikan pengawasan internal terhadap lembaga negara mandiri sehingga menambah sederetan panjang kompleksitas persoalan ketatanegaraan.

\footnotetext{
31 Lihat Pasal 30 ayat (1), (2), dan (4) Undang-Undang Dasar Negara Republik Indonesia Tahun 1945. Pasal 30 ayat (1), mengatur bahwa "Tiap-tiap warga Negara berhak dan wajib ikut serta dalam usaha pertahanan dan keamanan Negara". Pasal 30 ayat (2) "Usaha pertahanan dan keamanan Negara dilaksanakan melalui sistem pertahanan dan keamanan rakyat semesta oleh Tentara Nasional Indonesia dan Kepolisian Negara Republik Indonesia, sebagai kekuatan utama, dan rakyat, sebagai kekuatan pendukung". Pasal 30 ayat (4) "Kepolisian Negara Republik Indonesia sebagai alat Negara yang menjaga keamanan dan ketertiban masyarakat bertugas melindungi, mengayomi, melayani masyarakat, serta menegakkan hukum".
} 
Faktanya, lembaga negara baru yang dibentuk berdasarkan perintah langsung dari konstitusi relatif lebih jelas kedudukannya ketimbang lembaga negara yang dibentuk berdasarkan peraturan perundang-undangan di bawah UUD NRI Tahun 1945 seperti lembaga negara mandiri (state auxiliaries institutions). Pasca perubahan UUD 1945 ada tiga lembaga negara yang dibentuk yaitu Dewan Perwakilan Daerah, Mahkamah Konstitusi dan Komisi Yudisial sedangkan lembaga negara mandiri yang dibentuk berdasarkan peraturan perundang-undangan di bawah UUD NRI Tahun 1945 seperti lembaga negara mandiri yang dibentuk dengan Undang-Undang contoh misalnya Komisi Pemberantasan Korupsi, Komisi Pemilihan Umum (penyebutan dengan huruf kapital menunjukkan nama dari suatu lembaga), Komisi Penyiaran, Komisi Informasi Publik, Komisi Ombudsman, Komisi Kejaksaan, Kompolnas dan masih banyak komisi maupun dewan yang dibentuk paska perubahan UUD 1945 ini justru menimbulkan overlapping kewenangan seperti yang terjadi belum lama ini antara Komisi Pemberantasan Korupsi dengan Kepolisian Negara Republik Indonesia dalam penegakan hukum kasus dugaan korupsi di Polri yang mestinya kedua lembaga ini dapat bersinergi dalam penegakan hukumnya. Fakta ini sebenarnya cukup dapat menggugah para desainer kebijakan untuk segera membuat harmonisasi regulasi yang secara spesifik mengatur mengenai lembaga negara mandiri dari kewenangan, kedudukan dan pertanggungjawabannya.

Pertanggungjawaban merupakan upaya untuk menilai atau bahkan mengevaluasi secara komprehensif dari pelaksanaan masing-masing fungsi dari pemegang kekuasaan agar tetap terjaga prinsip check and balances. Hal ini dimaksudkan untuk mengurangi berbagai penyalahgunaan kekuasaan agar dapat dengan mudah melihat indikasi-indikasi penyalahgunaan kekuasaan. Selain itu agar para pemegang kekuasaan negara dapat bekerja lebih baik lagi sesuai dengan planning atau perencanaan. Yang patut dipertanyakan mengapa paska reformasi justru banyak terjadi pembentukan lembaga-lembaga negara mandiri yang ironisnya tidak dibarengi harmonisasi regulasi.

Mungkinkah lembaga negara yang lebih dulu ada belum dapat maksimal dalam menjalankan fungsinya? Apakah pemerintah sudah mempunyai grand design ketatanegaraan dalam menata struktur ketatanegaraan? Belum lagi persoalan pembentukan lembaga negara mandiri yang pembentukannya dengan Undang-Undang tetapi Undang-Undang nya tanpa disahkan oleh Presiden. Padahal dampak keluarnya Undang-Undang tersebut terbentuklah suatu lembaga negara mandiri, hal ini dapat menimbulkan kontroversi, seperti UU No. 32 Tahun 2002 tentang Penyiaran yang dalam perkembangannya terbentuklah Komisi Penyiaran Indonesia (KPI) yang kemudian diikuti oleh pembentukan Komisi Penyiaran Indonesia yang di bentuk di tingkat Provinsi atau sering disebut (Komisi Penyiaran Indonesia Daerah) bahkan sekarang hampir 33 provinsi sudah terbentuk KPID walaupun UU Penyiaran tidak ditandatangani (tidak disahkan) oleh Presiden karena menurut Pasal 20 ayat (5) secara konstitusional adalah sah. Dimana letak check and balances? Menjadi pro dan kontra sehingga ada kesan bahwa pembentuk UndangUndang (Presiden) sangat berhati-hati dalam menindaklanjuti Rancangan Undang-Undang tersebut dengan tidak melakukan pengesahan ataukah secara substantive masih setengah hati untuk disahkan.

Tidak ditandatanganinya Undang-Undang oleh Presiden tidak akan menyebabkan UndangUndang tersebut tidak sah seperti yang dinyatakan dalam Pasal 20 ayat (5) UUD NRI Tahun 1945 menyatakan Undang-Undang tanpa Pengesahan Presiden sah seperti berikut ini bahwa: Rancangan Undang-Undang yang telah disetujui bersama tersebut tidak disahkan oleh Presiden dalam waktu tiga puluh hari semenjak rancangan UndangUndang tersebut disetujui, Rancangan UndangUndang tersebut sah menjadi Undang-Undang dan wajib diundangkan. Pembentukan lembaga negara mandiri yang pembentukannya dengan Undang- 
Undang yang tidak ditandatangani oleh Presiden, dapat menimbulkan resistensi terhadap lembaga negara mandiri tersebut, mengapa sampai terjadi? Walaupun tidak terdapat konsekuensi hukum jika Presiden tidak mengesahkan RUU tersebut. Kepentingan, upaya untuk pencarian selamat, setengah hati dalam materi muatannya ataukah lemahnya kontrol Presiden terhadap menterimenterinya ketika mewakili dalam pembahasan RUU tersebut menjadi teka-teki jawaban. Merefleksi kebelakang ada empat Undang-Undang tanpa pengesahan Presiden yaitu UU Pembentukan Propinsi Kepulauan Riau (UU 25 No. Tahun 2002), UU Penyiaran (UU No. 32 Tahun 2002), UU Keuangan Negara (UU No. 17 Tahun 2003) dan UU Advokat (UU No. 18 Tahun 2003). Tetapi dalam konteks pembentukan lembaga negara mandiri hanya UU No. 32 Tahun 2002 tentang penyiaran yang menyangkut pembentukan Komisi Penyiaran Indonesia.

Mestinya pemerintah melihat pembentukan lembaga negara mandiri, secara komprehensif agar keberadaannya merupakan jawaban yang tepat dari kebutuhan riil masyarakat untuk membentuk lembaga negara mandiri. Keberadaan lembaga negara mandiri dalam struktur ketatanegaraan di Indonesia belum mempunyai desain secara konstitusional sehingga inilah yang menjadi persoalan utama. Peringatan satu dasawarsa Perubahan UUD 1945 saat yang tepat untuk merefleksi tentang kedudukan kelembagaan negara khususnya lembaga negara mandiri dalam struktur ketatanegaraan Indonesia. Overlapping kewenangan biasanya satu dengan yang lain disebabkan karena peraturan perundang-undangan yang berlaku tidak sejalan dengan kebijakan politik dan ketatanegaraan yang sedang berkembang, sehingga kedepan perlu ada penataan regulasi lembaga negara mandiri dalam konstitusi terlebih dahulu. Pembentukan lembaga negara mandiri idealnya diawali dari komando konstitusi sehingga menjadi terstruktur dalam konstitusi dan menjadi jelas kedudukannya dalam struktur ketatanegaraan. Selanjutnya desain kelembagaan negara pasca reformasi jumlahnya yang cukup banyak, belum lagi yang overlapping kewenangan juga belum mampu menampung aspirasi masyarakat. Akibatnya terjadi konflik kewenangan antar lembaga negara, komisi-komisi tak bisa dihindari lagi. Untuk itu agar organisasi suatu negara ini berjalan sesuai dengan komando konstitusi diadakan pengawasan peradilan dalam menjamin konstitusionalitas dengan adanya uji materiil, kebebasan dan hak-hak fundamental akan tetap terjaga, Mahkamah Konstitusi harus membuat putusan yang memiliki nilai dalam melindungi hakhak dan kebebasan warganegara.

\section{Penutup}

Fungsi masing-masing lembaga negara mandiri berbeda-beda tetapi frame lembaga negara mandiri dalam peraturan perundang-undangan yang harus diharmonisasikan seperti kedudukan dan mekanisme pertanggungjawaban, tata cara seleksi bahkan sampai pada penyebutan dari lembaga negara mandiri. Tulisan ini mempunyai tujuan agar ada harmonisasi regulasi lembaga negara mandiri supaya sesama lembaga negara mandiri tidak overlapping dalam menjalankan fungsinya dan lebih jauh lagi untuk mengkaji secara normatif lembaga negara Mandiri seperti komisi-komisi yang dibentuk secara ad-hoc dalam peraturan perundang-undangan jauh lebih efektif atau justru sebaliknya. Penataan regulasi ini bermaksud untuk penataan regulasi kelembagaan negara khususnya lembaga negara mandiri sehingga akan memudahkan pengawasan secara internal dan meminimalisir penyalahgunaan kekuasaan lembaga negara mandiri yang pembentukannya mestinya untuk menjawab tantangan kebutuhan masyarakat. Walaupun ada lembaga Mahkamah Konstitusi yang siap menjalankan wewenangnya apabila terjadi sengketa lembaga negara. Ke depan dengan kelemahan-kelemahan yang diketahui sejak awal maka akan dapat mengantisipasi penyalahgunaan kekuasaan dalam penyelenggaraan pemerintahan.

Penataan regulasi lembaga negara mandiri 
diawali dari perubahan konstitusi paling tidak hanya memuat amanah pembentukannya saja yang kemudian pelaksanaannya diatur lebih lanjut dengan Undang-Undang, dasar filosofisnya pembentukan Undang-Undang tidak boleh bertentangan dengan falsafah bangsa kemudian dasar sosiologisnya bahwa keberadaan lembaga negara mandiri sangat dibutuhkan oleh masyarakat dan secara yuridis punya landasan hukum dalam pembentukannya.

\section{DAFTAR PUSTAKA}

\section{A. Buku}

Asshiddiqie, Jimly, 2005, Hukum Tata Negara dan Pilar-Pilar Demokrasi, Konstitusi Press, Jakarta.

Azhary, 1995, Negara Hukum Indonesia, Analisis Yuridis Normatif tentang Unsur-Unsurnya, UI Pres, Jakarta.

Bellefroid, J. H. P., 1952, Inleiding tot de Rechtswetenschap in Nederland, Dekker \& De Vegt N.V. Nijmegen, Utrecht.

Franke, H., et al., 1990, Inleiden tot Rechtswetenschap, Gouda Quint D. Brouwer en zoon, Arnhem.

Indrayana, Denny, 2008, Indonesian Constitution Reform 1999-2002 An Evaluation of Constitutional-Making in Transition, Kompas Book Publishing, Jakarta.

Kant, Immanuel, 1887, The Philosophy of Law An Exposition of the Fundamental Principles of Jurisprudence as The Science of Right, (Terj. W. Hastie), B.D, T \& T Clark, Edinburg.

Kelsen, Hans, 1973, The General Theory of Law and State, (Terj. Anders Wedberg), Russel \& Russel, New York.

MD., Moh. Mahfud, 2010, Perdebatan Hukum Tata Negara Pasca Amandemen Konstitusi, Raja Grafindo Persada, Jakarta.

Nasution, Adnan Buyung, 2007, Arus Pemikiran Konstitutionalisme Hak Asasi Manusia dan Demokrasi, Kata Penerbit, Jakarta.

Pound, Roscoe, 2002, The Ideal Element in Law,
Liberty Fund, Indianapolis.

\section{B. Jurnal}

Burn, J. H., "Happiness and Utility: Jeremy Bentham's Equation", University College London, Vol. 17, No. 1, Maret 2005.

De Boer, Nick J., "Fundamental Rights and the EU Internal Market: Just how Fundamental are the EU Treaty Freedoms? A Normative Enquiry Based on John Rawls' Political Philosophy", Utrecht Law Review, Vol. 9, No. 1, Januari 2013.

La Porta, Rafael, et al., "Judicial Checks and Balances", Journal of Political Economy, Vol. 112, No. 2, 2004.

Pearlstein, Deborah N., "Form And Function In The National Security Constitution", Connecticut Law Review, Vol. 41, No. 5, Juli 2009.

Waldron, Jeremy, "The Rule of International Law", Harvard Journal of Law \& Public Policy, Vol. 30, No.1, 2006.

\section{Internet}

Veenhoven, Ruut, "Happiness as an Aim in Public Policy The Greatest Happiness Principle", http://www2.Eur.Nl/Fsw/Research/ Veenhoven, diakses 12 Maret 2013.

\section{Peraturan Perundang-undangan}

Undang-Undang Dasar Negara Republik Indonesia Tahun 1945. 